\title{
In Vitro Propagation of Wetland Medicinal Plant Lythrum salicaria L.
}

\author{
Betül Akın, Burcu Çetin*, Nüket Akanıl Bingöl \\ Department of Biology, Faculty of Sciences and Letters, University of Dumlupınar, Kütahya, Turkey \\ *burcu.cetin@dpu.edu.tr
}

Received: 12 February 2018

Accepted: 08 October 2018

DOI: $10.18466 /$ cbayarfbe. 393626

\begin{abstract}
The aim of this experiment is to develop a protocol to establish the in vitro propagation potential of Lythrum salicaria L (purple loosestrife). Seeds of $L$. salicaria were germinated and grown in Murashige Skoog (MS) medium for 30 days. At the end of 30 days, shoot tips of $L$. salicaria were cultured on MS medium supplemented with different combinations and concentrations of 6-benzylaminopurine (BAP; 1, 2 and 3 $\mathrm{mg} / \mathrm{L}$ ) and 1-naphthaleneacetic acid (NAA; 0, 0.1 and $0.5 \mathrm{mg} / \mathrm{L}$ ). Regenerated shoots were transferred to MS supplemented with varying concentrations of different auxins: NAA $(0.5$ and $1 \mathrm{mg} / \mathrm{L})$ and indole-3-butyric acid (IBA; 0.5 and $1.0 \mathrm{mg} / \mathrm{L}$ ) for rooting. Among the cytokinins investigated, BAP indicated the best response to initiate shoot elongation and multiple shoot formation alone. The highest number of shoot per explant (37 \pm 3.38$)$ was obtained in MS medium with $1 \mathrm{mg} / \mathrm{L}$ BAP. Although, the highest shoot length $(3.1 \mathrm{~cm} \pm 0.48)$ was found on medium with $1 \mathrm{mg} / \mathrm{L} \mathrm{BAP}+0.5 \mathrm{mg} / \mathrm{L} \mathrm{NAA}$, there were no statistically differences among all types of medium. Percentage of rooting, shoot length and root length were altered significantly with different concentrations of NAA and IBA. Thus, shoot length $(9.5 \mathrm{~cm} \pm 0.46)$, root length $(4.1 \mathrm{~cm} \pm 0.13)$ and the percentage of rooting $(100 \%)$ increased significantly with a concentration of $1 \mathrm{mg} / \mathrm{L}$ NAA. It was concluded that MS medium with $1 \mathrm{mg} / \mathrm{L}$ NAA has been superior for root development compared to other hormone concentrations.
\end{abstract}

Key words: Auxins, cytokinins, purple loosestrife, rooting, tissue culture.

\section{Introduction}

Plant tissue culture is the method use to maintain and grow plant cells, tissues or organs on artificial medium under stable temperature, light and humidity conditions. With this method, plant parts can be produced into several thousand of plantlets at the desired time and quality. Besides the conventional methods, tissue culture methods are considered as reliable and practical techniques for rapid propagation and conservation of plants. In recent years, plant tissue culture studies become very important areas about propagation, disease eradication, phytoremediation, plant development and secondary metabolite production [1, 2].

Purple loosestrife is a medicinal plant, containing tannins, flavones and anthocyanins, used medicinally to cure diarrhea, varicosis, hemorrhoid, bleeding gums and eczema [3]. On the other hand, L. salicaria is one of the plants used to detect pollution by heavy metals in wetlands [4]. It also has ability to accumulate heavy metals such as $\mathrm{Cr}, \mathrm{Cu}, \mathrm{Zn}$, $\mathrm{Fe}$ and $\mathrm{Pb}$ mostly in its root and thus it is used for phytoremediation of heavy metals $[5,6]$. Considering the importance of this plant, there are not many studies on in vitro propagation and root development of $L$. salicaria [7].
The aim of this experiment is to prepare a new protocol to establish the in vitro propagation potential of $L$. salicaria.

\section{Material and Methods}

For this study, L. salicaria seeds were collected along Porsuk River, Kütahya where plant showed optimum distribution. Seeds were air dried at room temperature and sealed in sample bags till further use. Before germination experiments, surface sterilization of seeds was carried out with $70 \%$ ethanol (Tekkim) for $3 \mathrm{~min}$ followed by $0.5 \%$ sodium hypochlorite $(\mathrm{NaOCl})$ solution containing a few drops of surfactant Tween-20 (Sigma) for $5 \mathrm{~min}$. After these sterilization steps, seeds were washed three times with sterile ultra-pure water. Murashige and Skoog (1962) medium containing mineral salts (Sigma), vitamins (Sigma), 3\% sucrose (Sigma) and 0.7\% agar (Merck) $(\mathrm{pH}=5.8)$ was used for germination experiments. The medium used in all experiments were autoclaved at $121^{\circ} \mathrm{C}$ for $20 \mathrm{~min}$. The sterilized seeds were placed into magenta vessels with plant growth regulator free MS medium [8] and kept in this medium for 30 days at $25 \pm 2^{\circ} \mathrm{C}$ and under a 16 hours photoperiod in growth chamber. After 30 days, shoot tips of in vitro germinated seedlings were placed on MS medium containing different concentrations of BAP 
(Sigma) and NAA (Sigma) for eight weeks (Table 1). For rooting studies, regenerated shoots (about 2 to $3 \mathrm{~cm}$ high) were transferred into MS medium with various concentrations of NAA ( 0.5 and $1 \mathrm{mg} / \mathrm{L})$ and IBA (Sigma) $(0.5$ and $1 \mathrm{mg} / \mathrm{L})$ to test in vitro rooting response.

At the end of the experiment, shoot number per explant, shoot length $(\mathrm{cm})$, root length $(\mathrm{cm})$, shoot rooting $(\%)$ and shoot frequency were measured for each growth regulators. Because plant developed too many roots, number of roots per shoot could not be counted.

\section{Statistical analysis}

Each experiment had three replicates containing five explants in each culture vessel. Statistical analyses of collected data were done by using JMP 6 SAS [9] program. ANOVA was performed on plant growth regulators as main effect. TUKEY-HSD was performed on means to detect differences in regulators.

\section{Results and Discussion}

Surface sterilized seeds had $100 \%$ germination when cultured in MS medium for 30 days. Among the plant growth regulators containing different concentrations of BAP and NAA used in this study, BAP alone has showed the best response to initiate shoot elongation and multiple shoot formation. As shown in Table 1, shoot elongation of L. salicaria seedlings were increased by $1 \mathrm{mg} / \mathrm{L}$ BAP. The highest number of shoot per explant $(37 \pm 3.38)$ was counted in MS medium containing $1 \mathrm{mg} / \mathrm{L}$ BAP growth regulator in the absence of NAA. Although the results showed that the highest shoot length $(3.1 \mathrm{~cm} \pm 0.48)$ was obtained on medium with $1 \mathrm{mg} / \mathrm{L} \mathrm{BAP}+0.5 \mathrm{mg} / \mathrm{L} \mathrm{NAA}$, there were no statistically differences among all types of medium. $100 \%$ of shoot rooting was observed in all $L$. salicaria plantlets cultured in all shoot mediums. The longest root length $(2.7 \mathrm{~cm} \pm 0.26)$ was determined on medium with $3 \mathrm{mg} / \mathrm{L} \mathrm{BAP}+0.1 \mathrm{mg} / \mathrm{L} \mathrm{NAA}$ (Table 1).

Table 1. Effects of BAP and NAA on shoot formation of L. salicaria after 30 days of shooting treatments.

\begin{tabular}{|c|c|c|c|c|}
\hline $\begin{array}{c}\text { Growth regulators } \\
(\mathrm{mg} / \mathrm{L})\end{array}$ & $\begin{array}{l}\text { Mean number of } \\
\text { shoots per explant }\end{array}$ & $\begin{array}{l}\text { Shoot length } \\
(\mathrm{cm})\end{array}$ & $\begin{array}{l}\text { Root length } \\
\text { (cm) }\end{array}$ & $\begin{array}{c}\text { Shoot rooting } \\
(\%)\end{array}$ \\
\hline $1 \mathrm{BAP}+0 \mathrm{NAA}$ & $37.0 \pm 3.38^{\mathrm{a}^{*}}$ & $2.7 \pm 0.13^{\mathrm{a}}$ & $1.5 \pm 0.08^{\mathrm{ab}}$ & 100 \\
\hline $1 \mathrm{BAP}+0.1 \mathrm{NAA}$ & $23.8 \pm 1.29 \mathrm{bcd}$ & $2.9 \pm 0.21^{\mathrm{a}}$ & $1.6 \pm 0.13^{b}$ & 100 \\
\hline $1 \mathrm{BAP}+0.5 \mathrm{NAA}$ & $22.6 \pm 2.22 \mathrm{bcd}$ & $3.1 \pm 0.48^{\mathrm{a}}$ & $1.0 \pm 0.29^{b}$ & 100 \\
\hline $1 \mathrm{BAP}+1 \mathrm{NAA}$ & $18.3 \pm 3.86^{\mathrm{cd}}$ & $2.9 \pm 0.21^{a}$ & $1.3 \pm 0.13^{b}$ & 100 \\
\hline $2 \mathrm{BAP}+0 \mathrm{NAA}$ & $26.7 \pm 1.29 \mathrm{abcd}$ & $2.4 \pm 0.30^{\mathrm{a}}$ & $1.4 \pm 0.15^{b}$ & 100 \\
\hline $2 \mathrm{BAP}+0.1 \mathrm{NAA}$ & $18.0 \pm 4.40^{\mathrm{cd}}$ & $2.8 \pm 0.31^{\mathrm{a}}$ & $1.4 \pm 0.16^{b}$ & 100 \\
\hline $2 \mathrm{BAP}+0.5 \mathrm{NAA}$ & $15.3 \pm 1.09^{\mathrm{d}}$ & $2.5 \pm 0.39^{\mathrm{a}}$ & $1.5 \pm 0.18^{a b}$ & 100 \\
\hline $2 \mathrm{BAP}+1 \mathrm{NAA}$ & $14.3 \pm 1.55^{\mathrm{d}}$ & $2.9 \pm 0.27^{\mathrm{a}}$ & $1.6 \pm 0.13^{b}$ & 100 \\
\hline $3 \mathrm{BAP}+0 \mathrm{NAA}$ & $30.4 \pm 3.09 a b c$ & $2.3 \pm 0.22^{a}$ & $1.9 \pm 0.25^{\mathrm{ab}}$ & 100 \\
\hline $3 \mathrm{BAP}+0.1 \mathrm{NAA}$ & $32.0 \pm 2.93^{\mathrm{ab}}$ & $2.3 \pm 0.21^{a}$ & $2.7 \pm 0.26^{\mathrm{a}}$ & 100 \\
\hline $3 \mathrm{BAP}+0.5 \mathrm{NAA}$ & $21.3 \pm 2.36^{\mathrm{bcd}}$ & $2.6 \pm 0.16^{\mathrm{a}}$ & $1.5 \pm 0.18^{b}$ & 100 \\
\hline $3 \mathrm{BAP}+1 \mathrm{NAA}$ & $27.4 \pm 1.95^{\mathrm{abcd}}$ & $2.7 \pm 0.14^{\mathrm{a}}$ & $1.7 \pm 0.16^{b}$ & 100 \\
\hline
\end{tabular}

* Means having the same letter in each column, do not different significantly at $\mathrm{p}<0.05$ (Tukey's test).

Most of plants need special in vitro culture conditions for multiplication. Cytokinins like kinetin, 6benzylaminopurine, thidiazuron and zeatin have commonly used in micropropagation studies [2, 10]. Plants may also require different culture medium for organogenesis [11]. In our study, BAP considerably encouraged the number of auxiliary shoots, and the highest multiplication rates of shoots were obtained in $1 \mathrm{mg} / \mathrm{L} \mathrm{BAP}$. The greater influence of BAP on proliferation and multiplication were also stated by Waoo et al. [12], Akın et al. [13] and Arab et al. [14]. In our study, medium containing $1 \mathrm{mg} / \mathrm{L}$ BAP induced the highest number of green and healthy adventitious shoots (Figure 1).

Increasing concentrations of BAP and NAA reduced the quality of plantlets even though these concentrations were significantly increased proliferation and root length.
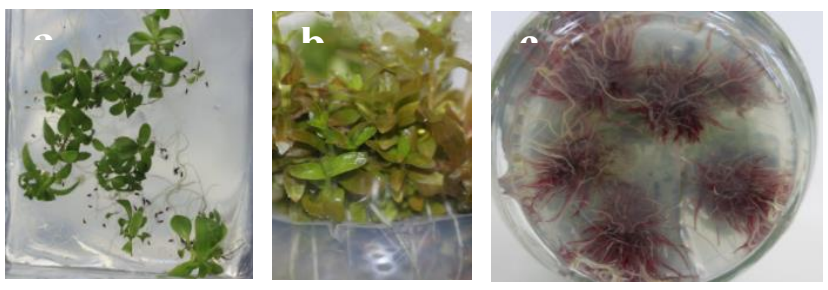

Figure 1. a. Seedlings cultured on MS medium at the end of the five weeks, b. In vitro shoot regeneration in $1 \mathrm{ppm}$ BAP, c. In vitro rooted shoots on MS medium containing 1 ppm NAA.

Thus, high concentrations of BAP causes necrosis, poor growth or abnormal shoots as mentioned in earlier studies [14].

In this experiment, the high number of shoots was detected in BAP mediums in the absence of NAA. Together with the increased of NAA plant growth regulator concentration in 
BAP mediums, shoot frequency decreased (Figure 2). In a study by Mehta et al., MS medium containing BAP and kinetin in the range $1.0-5.0 \mathrm{mg} / \mathrm{L}$ were used for shoot proliferation of Bacopa monnieri and they have obtained the maximum number of shoots per explant was in $1 \mathrm{mg} / \mathrm{L}$ BAP concentration [15]. Similar multiplication response was also obtained in shoot tips of Erodium sibthorpianum in $1 \mathrm{mg} / \mathrm{L} \mathrm{BAP} \mathrm{[13].} \mathrm{According} \mathrm{to} \mathrm{Otroshy} \mathrm{et} \mathrm{al.} \mathrm{[16],} \mathrm{the}$ highest number of shoots per explant for leaf and cotyledons has been recorded in the presence of BAP (2 $\mathrm{mg} / \mathrm{L})$.

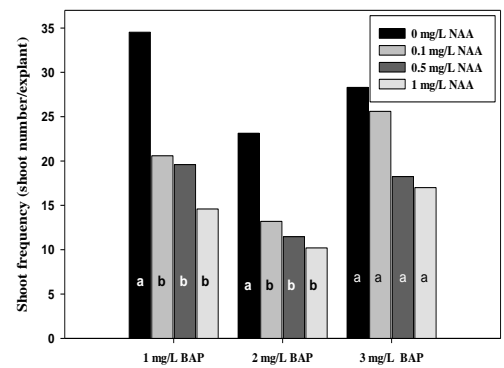

Figure 2. Effect of BAP and NAA concentrations on shoot frequency of $L$. salicaria.

Auxins (IAA, NAA, IBA) are the most important plant growth regulators for adventitious root development [17]. While auxins generally induce root growth of plants in low concentrations, it blocks root development in high concentrations [18]. In this study, MS mediums containing different concentrations of NAA and IBA plant growth regulators were considerably effected the percentage of rooting, shoot length and root length of $L$. salicaria. It was also found that, shoot length $(9.5 \mathrm{~cm} \pm 0.46)$, root length $(4.1 \mathrm{~cm} \pm 0.13)$, and percentage of rooting $(100 \%)$ were increased in MS medium containing $1 \mathrm{mg} / \mathrm{L}$ NAA (Table 2). Roots of $L$. salicaria were reddish in $1 \mathrm{mg} / \mathrm{L}$ NAA MS medium. Resende et al. [19] stated that endemic plant Lippia rotundifolia produced best adventitious roots at 0.44 $\mu \mathrm{M}$ NAA concentration. According to Tolera [20], in sugarcane variety N14, $1 \mathrm{mg} / \mathrm{L}$ NAA without IBA was the best for rooting response.

Table 2. Effects of auxins (NAA and IBA) on shoot length and root formation of $L$. salicaria.

\begin{tabular}{cccc}
\hline $\begin{array}{c}\text { Growth } \\
\text { regulators } \\
\text { (mg/L) }\end{array}$ & $\begin{array}{c}\text { Shoot length } \\
(\mathbf{c m})\end{array}$ & $\begin{array}{c}\text { Root } \\
\text { length } \\
\text { (cm) }\end{array}$ & Rooting (\%) \\
\hline $\mathbf{0 . 5}$ NAA & $8.0 \pm 0.16^{\mathbf{b}^{*}}$ & $4.0 \pm 0.16^{\text {ab }}$ & 100 \\
$\mathbf{1 . 0}_{\mathbf{N A A}}$ & $9.5 \pm 0.46^{\mathbf{a}}$ & $4.1 \pm 0.13^{\mathbf{a}}$ & 100 \\
$\mathbf{0 . 5}$ IBA & $8.7 \pm 0.39^{\text {ab }}$ & $3.4 \pm 0.14^{\mathbf{b}}$ & 100 \\
$\mathbf{1 . 0}^{\mathbf{I B A}}$ & $8.5 \pm 0.41^{\text {ab }}$ & $3.8 \pm 0.20^{\text {ab }}$ & 100 \\
\hline
\end{tabular}

* Means having the same letter in each column, do not different significantly at $\mathrm{p}<0.05$ (Tukey's test).
Among the two auxins we used, NAA was found to superior to IBA and $1 \mathrm{mg} / \mathrm{L}$ NAA was the best MS medium for root growth of L. salicaria.

\section{Conclusion}

Although $L$. salicaria is a medicinal and phytoremediator plant, there are a few studies on micropropagation of $L$. salicaria. It's very important to improve root system of $L$. salicaria for phytoremediation of polluted freshwaters because this plant can accumulate heavy metals in its root. L. salicaria plantlets can be used as source plant in phytoremediation researches in the future.

\section{References}

1. Hussain, A, Qarshi, I.A, Nazir, H, Ullah, I, Plant Tissue Culture: Current Status and Opportunities. In: Leva, A, Rinaldi, L.M.R (eds) Recent Advances in Plant in vitro Culture, Intech, 2012, pp 1-28.

2. Sarasan, V, Cripps, R, Ramsay, M.M, Atherton, C, McMichen, M, Prendergast, G, Rowntree, J.K, Conservation in vitro of threatened plants-Progress in the past decade, In Vitro Cellular \& Developmental Biology Plant, 2006, 42, 206-214.

3. Humadi, S.S, Istudor, V, Lythrum salicaria (purple loosestrife) Medicinal use, extraction and identification of its total phenolic compounds, Farmacia, 2009, 57(2), 192-200.

4. Mal, T.K, Uveges, J.L, Turk, K.W, Fluctuating asymmetry as an ecological indicator of heavy metal stress in Lythrum salicaria, Ecological Indicators, 2002, 1, 189-195.

5. Nicholls, A.M, Mal, T.K, Effects of lead and copper exposure on growth of an invasive weed, Lythrum salicaria L. (Purple Loosestrife), The Ohio Journal of Science, 2003, 103(5), 129-133.

6. Sun, H, Wang, Z, Gao, P, Liu, P, Selection of aquatic plants for phytoremediation of heavy metal in electroplate wastewater, Acta Physiologiae Plantarum, 2013, 35(2), 355-364.

7. Turker, A.U, Yucesan, B, Gurel, E, An efficient in vitro regeneration system for Lythrum salicaria, Biologia Plantarum, 2009, 53(4), 750754.

8. Murashige, T, Skoog, F, A revised medium for rapid growth and bioassays with tobacco tissue cultures, Physiologia Plantarum, 1962, $15,473-497$.

9. JMP SAS. SAS Institute Inc. USA, 1995.

10. Rout G.R, Effect of cytokinins and auxins on micropropagation of Clitoria ternatea L., Biology Letters, 2004, 41(1), 21-26.

11. Nas, M.N, Read, P.E, A hypothesis for the development of a defined tissue culture medium of higher plants and micropropagation of hazelnuts, Scientia Horticulturae, 2004, 101, 189-200.

12. Waoo, A.A, Khare, S, Ganguli, S, In-vitro propagation of Datura innoxia from nodal and shoot tip explants, World Journal of Environmental Engineering, 2013, 1(1), 1-4.

13. Akın, B, Kocaçalışkan, İ, Güleryüz, G, Micropropagation of Erodium sibthorpianum subsp. sibthorpianum, an endemic threatened species 
Celal Bayar University Journal of Science

Volume 14, Issue 4, 2018, p 369-372

of Uludağ Mountain (Bursa-Turkey), Turkish Journal of Botany, 2014, 38, 148-155.

14. Arab, M.M, Yadollahi, A, Shojaeiyan, A, Shokri, S, Ghojah, S.M, Effects of nutrient media, different cytokinin types and their concentrations on in vitro multiplication of G N15 (hybrid of almond peach) vegetative rootstock, Journal of Genetic Engineering and Biotechnology, 2014, 12, 81-87.

15. Mehta, J, Ansari, R, Syedy, M, Khan, S, Sharma, S, Gupta, N, Rathore, R, Vaishnav, K, An effective method for high frequency multiple shoots regeneration and callus induction of Bacopa monnieri (L.) Pennel: An important medicinal plant, Asian Journal of Plant Science and Research, 2012, 2(5), 620-626.

16. Otroshya, M, Khalilia, Z, Ebrahimi, M.A, Nekoui, M.K, Moradi, K, Effect of growth regulators and explant on plant regeneration of Solanum lycopersicum L. var. cerasiforme, Russian Agricultural Sciences, 2013, 39(3), 226-235.
17. Sauer, M, Robert, S, Kleine-Vehn, J, Auxin: simply complicated, Journal of Experimental Botany, 2013, 64(9), 2565-2577.

18. Caspar, T, Faivre-Rampant, O, Kevers, C, Dommes, J, Hausman, J.F, Auxins in the biology of roots. In: Waisel, Y, Eshel, A, Kafkafi, U (eds) Plant roots: The hidden half, 3rd edn. Marcel Dekker, Inc. New York, 2002, pp 576-608.

19. Resende, C.F, Bianchetti, R.E, Oliveira A.M, Braga V.F, Peixoto P.H.P, In vitro propagation and acclimatization of Lippia rotundifolia, an endemic species of Brazilian Campos Rupestres, Revista Ciencia Agronômica, 2015, 46(3), 582-589.

20. Tolera, B, Effects of naphthalene acetic acid (NAA) and indole-3butyric acid (IBA) on in vitro rooting of sugarcane (Saccharum officinarum L.) micro-shoots, Journal of Biotechnology \& Biomaterials, 2016, 6, 1-5. 